Bella mujer muerta

que estás en mí llorando la vida, y volverás a morir cuando el paisaje [negro deje sus carbones profundos en mis [retinas; Madre, corriendo pueblos y hori[zontes, mi corazón de hombre triste ha [llegado a tu Lima.

Carlos Préndez Saldías ha llegado hace tiempo a la madurez poética; pero ahora se puede decir que está llegando a la cúspide de su torre de ensueños. Este libro escrito bajo Cielo Extranjero lo afirma así.-F. Santiván.

\section{EL MITIN DE LAS MARIPOSAS, por} Julio Barrenechea.

¡Estudiante y poeta! El autor ha juntado los dos títulos más bellos que pueden llenar el alma de un joven. Estudiante en quien todas las inquietudes actuales encontraron un eco armonioso, y poeta en el mejor sentido de la palabra, como lo ha revelado su libro, para mirar la vida y los hombres.

No lo conocíamos como poeta. Sabíamos sí de su actuación destacada en el elemento estudiantil, con motivo de las incidencias últimas, que le valió persecuciones. Sólo ahora, El mitin de las mariposas (1) nos lo ha mostrado como poeta. Y afortunadamente podemos afirmar, sin temor de equivocarnos, que nos encontramos frente a un poeta, a un poeta auténtico, que destacará con el tiempo su per-

(1) Editorial Minarete. Santiago, 1930. sonalidad entre la turbamulta de simuladores, escritores ocasionales de renglones cortos sin sentido, que, amparados bajo la capa amplísima de sèr "nuevos", sólo atinan a poblar el ambiente literario de estridencias incoherentes.

Julio Barrenechea puede quedar clasificado entre los poetas nuevos. Pero entre ellos conserva una personalidad independiente de los módulos de las últimas tendencias y al través de ellas ha tomado las novedades que permanecerán incorporadas a las mejores corriertes poéticas. Desde luego, aquellas características sobre las cuales se han edificado todos los últimos «ismos» pueden reducirse a una sola: la novedad de las imágenes. $\mathrm{Y}$ es curioso observar que mientras todos los nuevos no hacen otra cosa que exponè liberación absoluta de lo que han llamado los elementos de la retórica vieja, sus producciones sólo son colecciones de imágenes, vale decir metáforas, figuras retóricas de reconocida antigüedad. Si las imágenes coleccionadas en los poemas nuevos fueran siempre nuevas, es decir, contuvieran un elemento novedoso que formara un acierto imaginativo, la poesía nueva no sería combatida en la forma que lo ha sido hasta ahora; pero ocurre que los poemas nuevos, si contienen una imagen novedosa, carecen en cambio de todas las otras cualidades que hastá ahora se han considerado esenciales en un poema, empezando por la coherencia de las ideas $\mathrm{y}$-esto es más importante-de la emotividad poética. 
En Barrenechea el temperamento poético está basado en esas condiciones perdurables. De sus versos fluye permanentemente una emotividad intensa y rica, contenida por un acento leve de humorismc. El sentido poético de la obra de Barrenechea está marcado por las condiciones indicadas: emoción y humorismo. Este humorismo a ratos ingenuo y provinciano, se transforma en algunos de sus poemas en ironía de la mejor ley, pero la tónica que predomina es la de una emoción sincera ante las cosas pequeñas, humildes, unida a un humorismo que adquiere en ocasiones, sin caer nunca en lo grotesco, un desmayado acento nostalgioso. Influencias de consideración se encuentran en sus versos, donde sobre las de Carriego y Sabat Ercasty predomina la inevitable de Neruda. Y aquí cabe hacer una afirmación rotunda: los versos mejores del poeta son precisamente aquellos en que su personalidad se manifiesta libre y espontánea; tan pronto se notan las influencias que hemos señalado, los poemas se convierten en repeticiones poco originales de motivos cantados por otros poetas, con las palabras de estos otros poetas, que no tienen nada de la personalidad de Barrenechea. Así podemos ver su Monólogo desencantado (pág. 51), en que el recuerdo del Neruda de Farewell y de la canción N.॰ 20, se hace presente con sus mismas palabras:

La sombra de mis ojos se hume[deció en tus ojos.
$\mathrm{Y}$ era blanca en mis manos, la [sombra de tus manos.

Idéntico reparo puede hacerse a Fruta de invierno (pág. 53), a Madrigal frágil (pág. 55), poemas en que Neruda con su encanto absorbente ha encasillado y limitado en términos lastimosos la personalidad diferente de Barrenechea. En Nocturno de Danza, Sabat Ercasty ha disminuído su vigor original y se manifiesta en Barrenechea, en gritos estentóreos y un poquitín como de feria:

Baila noche. Baila. Baila.

Danza la danza. Dánzala.

Desespérate. Baila.

En realidad los únicos que pueden desesperarse son los lectores, que ven al poeta buscando acentos que no cuadran a su temperamento personal, a su cuerda poética íntima y profunda, que le ha arrancado poemas tan bellos y completos, como Amor Universitario, en que la emoción, de una deliciosa simpleza, está cantada en forma original, pura y de una aparente naturalidad encantadora:

Pero qué estudiante más flojo. No oye ninguna explicación.

Se lo pasa ideando cielos y armonías de otro color.

En clase se lleva saltando por las bancas, entre ella y yo.

Sale a veces por la ventana

y nos dice: Vengan al sol! Claro,

si no le pasan lista, como hacen con nosotros dos. 
Y se ercanta con distraerme si atiendo por casualidad.

Fabrica con los ojos de ella palomitas de papel azul, y me las lanza mientras habla cosas serias el profesor.

Los compañeros lo conocen y hacen sus bromas al pasar. Notan un acento extranjero en nuestra manera de hablar.

Nuestro amor universitario..... Puede ser que no se quede atrás.

Que se reciba con nosotros. Que no se canse de estudiar.

Nuestro amor es otro estudiante llegado a la Universidad. En el Liceo de mis sueños hizo sus años de escolar.

Todas las cualidades que hemos señalado en Barrenechea se encuentran en el bellísimo poema trascrito. Su autor, poeta de corazón, ha cantado una emoción pura y sencilla con sencillez y pureza. Pero su canto demuestra su temperamento, y de un motivo si se quiere pueril, ha logrado componer una obra de arte pequeñita y duradera.

Es satisfactorio comprobar que nos encontramos frente a un nuevo poeta de nuestra tierra, un poeta que con el trascurso de la vida, profundizando su visión del mundo, de los centimientos y de las cosas, nos puede regalar un canto de particular belleza. Deploramos que Barrenechea no asigne mayor importancia a sus facultades. EEste es mi oficio, crear las mariposas y echarlas a volar», dice en el prólogo de su libro. Pero sus lectores, los que admiramos sus condiciones y creemos que puede ser el creador de una obra poética de valor, le pediríamos que ponga su alma toda y toda su inteligencia en la creación de sus futuras mariposas. Y la colección de ellas será la mejor defensa y la mejor crítica del poeta. -Abel Valdés A.

\section{CRITICA LITERARIA}

PARADOJA SOBRE LAS CLASES SOCiales EN LA literatura, por Raúl Silva Castro. AcerCa DE LA literatura ChILENa, por $M a$ nuel Rojas.

El diálogo, cuyas excelencias filosóficas han demostrado numerosos autores, es, a juicio nuestro, indispensable en la dilucidación de problemas actuales. En el análisis de la realidad presente se corre siempre el riesgo de la visión unilateral. En cambio, el sistema de tesis $y$ antítesis ofrece al lector una visión panorámica, de la cual es posible desprender una conclusión. De ahí el mérito de la labor que realiza en sus reuniones semanales el grupo Indice y el valor singular de la publicación que comentamos (1).

El año 1930, sin lugar a dudas, señalará la fecha de nacimiento de una generación literaria. Algunos de sus miembros actúan hace tiempo en diarios y revistas; otros son au-

(1) Imprenta Universitaria. Santiago, 1930. 